\title{
Hvorfor er Durkheim, Weber og Searle relevante? Et svar til Nicolay B. Johansen
}

\author{
Av Professor emeritus Leif Petter Olaussen (IKRS, UiO)
}

Overskriften på Nicolay B. Johansens svarartikkel til meg (Johansen (2015: 213) formidler at han er opptatt av min bruk av teori i det jeg har skrevet om kriminalitetens eksistens. Han viser til at jeg har trukket veksler på Durkheim, Weber, Searle og Tranøy. Dette blir for mange referanser, skriver han, og jeg setter sammen svært motsetningsfylte forfattere på en måte som ikke gir ordentlig mening. I følge Johansen «fremstår det som om [jeg] prøver å hevde at disse forfatterne på en eller annen måte kan settes sammen til en helthetlig sosiologisk fellesnevner». (Johansen 2015:215) Han er ikke overbevist om at det vil være mulig, og det jeg har skrevet «framstår faktisk nokså usammenhengende». Han ser ut til å mene (s. 213) at Durkheim og Weber ikke kan kombineres fordi Weber var metodologisk individualist, mens Durkheim ikke var det, og Johansen spør (s. 214) hvordan Searle kan gjøres kompatibel med Durkheim, siden Searle i følge Johansen «er opptatt av å avkle sosiale fenomener dere sui generis egenskaper».

Kriminalitetens ontologi er etter min oppfatning av sosial karakter. Det er dette jeg har forsøkt å begrunne ved å trekke veksler på mange forfattere som etter min vurdering står hverandre så nær hva sosial ontologi angår, at jeg ikke ser noen problemer med å bruke dem slik jeg har gjort. Dette medfører selvsagt ikke at jeg tror at de nevnte forfatterne kan «settes sammen til en helhetlig sosiologisk fellesnevner». Det er bare noe Johansen tillegger meg.

På to punkter formulerer Johansen seg så konkret at det er mulig å svare. Det gjelder forholdet mellom Durkheim og Searle, og ditto for Durkheim og Weber.

\section{Durkheim og Searle}

Jeg har vist til at Durkheim var sterkt opptatt av sosiale fakta som påvirker oss som en tvingende kraft utenfor individet, men som samtidig finnes inne i oss (Olaussen 2004 s. 25). I forordet til andre utgave av sin metodelære skrev Durkheim dessuten eksplisitt at sosiale fakta skapes ved sosial samhandling mellom individer som frembringer noe nytt, institusjoner:

«No doubt the individual plays a part in their creation. But in order for a social fact to exist, several individuals at the very least must have interacted together and the resulting combination 
must have given rise to some new production. As the synthesis occurs outside each one of us (since a plurality of consciousness are involved) it has necessarily the effect of crystallizing, of instituting outside ourselves, certain modes of action and certain ways of judging which are independent of the particular individual will considered separately. (...) [T] here is one word which (...) expresses moderately well this very special kind of existence; it is that of institution.» (Durkheim 1982, s. 45.)

Institusjonelle fakta eller ordninger - bestemte handlinger og vurderingsmåter krystalliseres som noe annet enn enkeltindivider og får derved en eksistens sui generis - er følgelig ikke uten forbindelse til individnivået. De har tvert imot sin opprinnelse i samhandling mellom individer.

Selv om Durkheims ontologi når det gjelder sosiale institusjoner er mer rudimentær enn Searls, kan deres oppfatninger etter min mening lett forenes, til tross for at Searles argumentasjon skiller seg markant fra Durkheims. For Searle er kollektiv intensjonalitet en forutsetning for og årsak til institusjonelle (sosiale) realiteter som penger, ekteskap, eiendom, universitet, regjering brannkorps, politi, etc. De oppstår ikke med mindre det finnes en «vi-intensjonalitet» i tilstrekkelig mange (individuelle hoder) til at en kollektiv ordning (X) blir etablert. ${ }^{1}$ Dette er svært kompatibelt med Durkheim. Det nye og sosiologisk viktige ved Searle er hans påpekning av menneskers mulighet til gjøre ting ved å handle språklig, takket være språkets performative karakter. Dette gjør at sosiale fenomener er vesensforskjellige fra naturfenomener og må forstås deretter. ${ }^{2}$ For Searls forståelse av sosiale fenomener som sosiale institusjoner er det viktig at vi kan erklære kollektivt at «X skal gjelde som Y i C», og når X har oppnådd kollektiv anerkjennelse som $\mathrm{Y}$ i C, foreligger $\mathrm{X}$ som en institusjonalisert ordning. Det betyr at $\mathrm{X}$ har blitt en sosial realitet $\mathrm{i} \mathrm{C}$, med «deontisk makt» på grunn av rettigheter, plikter, tillatelser, fullmakter, osv. som sosiale institusjoner er formidlere av (Searle 2010 s. 8-9). Kollektivt har vi evne til å skape sociale realiteter med deontisk makt ved å erklære dem som eksisterende - fordi dette formidler hvem som har (hvilke) rettigheder, plikter, tillatelser osv. Det nevnte grunnlaget for deontisk makt gjør at sosiale institusjoner er epistemologisk objektive, mens deres avhengighet av kollektiv anerkjennelse gjør dem ontologisk subjektive, jfr. Olaussen 2004 s. 35-36.

At Durkheim ikke hadde Searles innsikt i språkets sosiale betydning for å forstå sosiale institusjoner bedre, skaper etter min oppfatning ingen uoverstigelig kløft mellom deres forståelser. Det mest grunnleggende var de enige om: Sosiale institusjoner er uløselig knyttet til at individer i fellesskap forsøker å finne felles svar på et problem - for eksempel kriminalitet. Da oppretter de en maktinstitusjon - med fullmakter, rettigheter, plikter, osv., altså med deontisk makt. Jeg er 
ute av stand til å se at dette ikke skulle være kompatibelt med Durkheim forståelse av sosiale institusjoner, selv om oppfatningene selvsagt ikke er like.

\section{Weber og Durkheim}

Johansen hevder (s. 213) at jeg har lagd en ukommentert sammenstilling av Weber og Durkheim. Dette gjør at Johansen er ganske usikker på hva jeg mener, skriver han. Jeg skulle gjerne forsøkt å oppklare, men Johansen oppgir (som vanlig) ingen henvisning til hvilken tekst det gjelder.

Jeg har inntrykk av at Johansens usikkerhet skyldes hans polære oppfatning (s. 213) av Weber som metodologisk individualist og Durkheim som hans motsetning på dette punkt. Etter min oppfatning er det imidlertid lett å overdrive motsetningen mellom de to, og å overse grunnleggende likheter. Når det gjelder sosiologiens formål eller gjenstand, skrev Durkheim i det forordet som ble sitert ovenfor at «sosiologien kan defineres som vitenskapen om institusjoner, deres tilblivelse og utvikling» (Durkheim 1982 s. 45). For Weber var sosiologi «en vitenskap som fortolkende forstår sosial handling og dermed vil forklare dens forløp og virkninger ut fra dens årsaker» (Weber 1999 s. 26). Og «den forstående sosiologien (i vår forstand) behandler enkeltindividet og dets handlinger som sin minste enhet, som sitt «atom» - hvis vi her for en gangs skyld skal tillate oss å gjøre denne i seg selv tvilsomme sammenligningen» (Weber 1999 s. 64). Det virker derfor ikke som Durkheim og Weber har samme vitenskap i sine tanker, slik Johansen trolig sikter til. Men likevel, deres forståelse av forholdet mellom sosiale ordninger (struktur) og individuell atferd er slående lik, og derfor er de relevante for å forstå hva kriminalitet er.

Weber var fullt på det rene med at enkeltindivider ikke er atomer, og at menneskers atferd i meget stor grad påvirkes av at vi er innvevd med hverandre i naturlige, interessemessige og institusjonelle fellesskap, jfr. Olaussen (2004 s. 2628). Og dette har betydning for å forstå handlingers mening, som Weber mente at sosilogien skulle være opptatt av. Hvis man skal forstå at en «tyv» eller «drapsmann» skjuler seg og sin handling, så må man se forsøkene på å skjule i lys av «nettopp de ordninger som han subjektivt bevisst bryter med» (Weber $1999 \mathrm{~s}$. 68). Videre skrev han «hvis drapsmannen ikke lenger bekymrer seg for de ordninger som ham forbryter seg mot, fordi forbrytelsen ikke har noen konsekvenser for ham - i slike tilfeller har ordningene ikke lenger noen empirisk eksistens, og heller ikke sammenslutningen [som fastsatte ordningene]» (Weber 1999, s. 69). Individuelle handlingers mening må man i følge Weber blant annet søke etter blant sosiale ordninger som individet mener/antar er gyldige. Det gjelder også for tyverier, drap og annen kriminalitet. Generelt skrev han at det som interesserer den forstående sosiologien er handlingens meningsfulle forbindelser til om- og 
fremfor alt utenverdenen. (Weber 1999 s. 58). Fysiologi og psykologiske aspekter var ikke relevante for den forstående sosiologien, mente han (1.c.).

Dette ligner svært på mye som også Durkheim har skrevet om forholdet mellom individ og sosiale institusjoner/ordninger. I en note ${ }^{3}$ til teksten jeg siterte like ovenfor, skrev Durkheim at selv om sosiale praksiser gjennomtrenger oss utenfra, så tilpasser vi oss ikke dem på en passiv måte. Vi forholder oss ofte individuelt til kollektive institusjoner og kan sette vårt stempel på dem, slik at vi i noen grad kan skape vår egen moral, religion og teknikker, selv om området for tillatt variasjon er begrenset. Mulighetene for tillatte individuelle atferdstilpasninger er meget liten på det religiøse og moralsk området, men større på det økonomiske, før de blir kriminalitet, mente han. Men også på det økonomiske området finnes det institusjonelle grenser man ikke kan overtre.

For både Weber og Durkheim var det helt grunnleggende at menneskers individuelle atferd - også atferd som det er vanlig å kalle kriminalitet - må forstås $\mathrm{i}$ lys av sosiale ordninger som er ment å skulle regulere slik atferd. Når de skriver om kriminalitet, forutsetter begge at kriminalitet finnes som en institusjonalisert samfunnsmessig ordning. Kriminalitetens sosiale ontologi er opplagt både for Durkheim og Weber.

Jeg ser derfor ikke hvilken relevans det har at Weber overfladisk kan omtales som metodologisk individualist, mens dette ikke gjelder Durkheim.

Med dette anser jeg diskusjonen med Nicolay B. Johansen som avsluttet.

\section{Noter}

1. Se Searle (1998, s. 118-124).

2. Se Searle (2002) særlig kapitlene 7-10 (s.106-179). Counsciousness and Language. Cambridge: Cambridge university Press.

3. Durkheim (1982, note 6 s. 47).

\section{Referanser}

Durkheim, E (1982): The Rules of Sociological Method. [Edited with an Introduction by Steven Lukes, translated by W.D. Halls] New York: The free press.

Johansen, N.B. (2015): «Kriminologers bruk av teori: Svar til Leif Petter Olaussen». Nordisk Tidsskrift for Kriminalvidenskab, nr. 2, s. 212-218.

Olaussen, L.P. (2004): «Hvorfor er kriminailitet en social realitet?» Nordisk Tidsskrift for Kriminalvidenskab, $\mathrm{nr}$ 1, s. 24-38.

Searle, J.R. (1998): Mind, Language and Society. Philosophy in the Real World. New York: Basic Books.

Searle, J.R. (2002): Consciousness and Language. Cambridge: Cambridge university Press.

Searle, J.R. (2010): Making The Social World. The Structure of Human Civilization.

Weber, M. (1999): Verdi og handling. Oslo: Pax forlag. 